\title{
PENGARUH ATRIBUT PRODUK TERHADAP LOYALITAS PELANGGAN TUPPERWARE \\ (Studi pada Dosen dan Tenaga Kependidikan Fakultas Ekonomi Universitas Tadulako)
}

\author{
SUKMAWATI \\ SUARDI \\ ZAKIYAH ZAHARA \\ Jurusan Manajemen, Fakultas Ekonomi, Universitas Tadulako \\ Email: Sukmawatiy74@gmail.com
}

\begin{abstract}
This study aims to determine the effect of Produrict Attbutes [Brand (X1), Packaging (X2), Label (X3), Service (X4), and Warranty (X5)] Tupperware Customer Loyalty (Study on Lecturers and Teaching Personnel Faculty of Economics University of Tadulako ). The type of research used is Causal Descriptive. Population in this research is Lecturer and Teacher of Faculty of Economics of University of Tadulako loyal use Tupperware product. Sampling technique in this study using Purposive Sampling, with the number of samples of 60 respondents. Data collection using questionnaires. The method of analysis using multiple linear regression analysis. Simultaneous test results (Test F) show that variables [Brand (X1), Packaging (X2), Label (X3), Service (X4), and Warranty (X5)] together significantly influence Tupperware Customer Loyalty. Partial test results indicate that Brand (X1), Label (X3), Service (X4), and Warranty (X5) variables significantly influence Tupperware Customer Loyalty. While Packaging variable (X2) partially no significant effect on Customer Loyalty Tupperware (Study on Lecturer and Teaching Personnel Faculty of Economics, University of Tadulako).
\end{abstract}

Keywords: Product Attributes, Customer Loyalty.

\section{ABSTRAK}

Penelitian ini bertujuan untuk mengetahui pengaruh Atribut Produk [Merek (X1), Kemasan (X2), Label (X3), Pelayanan (X4), dan Garansi (X5)] Terhadap Loyalitas Pelanggan Tupperware (Studi pada Dosen dan Tenaga Kependidikan Fakultas Ekonomi Universitas Tadulako). Jenis penelitian yang digunakan adalah Deskriptif Kausal. Populasi dalam penelitian ini adalah Dosen dan Tenaga Kependidikan Fakultaas Ekonomi Universitas Tadulako yang loyal menggunakan produk Tupperware. Teknik penarikan sampel dalam penelitian ini menggunakan Purposive Sampling, dengan jumlah sampel sebanyak 60 responden. Pengambilan data menggunakan kuesioner. Metode analisis menggunakan analisis regresi linear berganda. Hasil pengujian simultan (Uji F) menunjukan bahwa variabel [Merek (X1), Kemasan (X2), Label (X3), Pelayanan (X4), dan Garansi (X5)] secara bersamasama berpengaruh signifikan terhadap Loyalitas Pelanggan Tupperware. Hasil pengujian parsial menunjukkan bahwa variabel Merek (X1), Label (X3), Pelayanan (X4), dan Garansi (X5) berpengaruh secara signifikansi terhadap Loyalitas Pelanggan Tupperware. Sedangkan variabel Kemasan (X2) secara parsial tidak berpengaruh signifikan terhadap Loyalitas Pelanggan Tupperware (Studi pada Dosen dan Tenaga Kependidikan Fakultas Ekonomi Universitas Tadulako).

Kata Kunci: Atribut Produk, Loyalitas Pelanggan..

\section{PENDAHULUAN}

Keberhasilan Tupperware dalam menarik hati para konsumen semakin jelas terlihat seperti di Kota Palu telah ramai penjualan produk Tupperware tanpa melihat lagi waktu dan tempat selalu saja terdapat obrolan-obrolan hingga transaksi jual beli di antara ibu-ibu rumah tangga. Produk ini selalu menjadi produk yang ditawarkan dimana saja yang menjadi tempat perkumpulan orang-orang seperti di tempat arisan, komunitas-komunitas, kantor, bahkan kampus dimana produk ini identik dengan para ibu-ibu. 
Kampus merupakan wilayah akademis yang sangat tidak mungkin jika tidak adanya perempuan/para ibu di dalamnya. Merupakan sesuatu yang alami bagi seorang perempuan terlebih lagi bagi ibu rumah tangga yang saling membagikan informasi mengenai sesuatu yang sangat identik bagi mereka salah satunya produk-produk rumah tangga. Misalnya di Universitas Tadulako khususnya di ruang lingkup Fakultas Ekonomi merupakan fakultas yang sangat dekat dengan dunia bisnis karena bidang ilmu yang dipelajari berkaitan dengan hal tersebut, sehingga berdasarkan pengamatan peneliti para dosen dan tenaga kependidikan disaat-saat istirahat ataupun waktu luang yang dimiliki seperti tidak adanya jam mengajar dan tidak padatnya tugas yang harus diselesaikan, menggunakan waktunya untuk saling Sharing dan melakukan transaksi-transaksi jual beli produk seperti Tupperware. Ditambah lagi produk ini merupakan produk popular dikalangan ibu rumah tangga yang ditawarkan sebagai solusi bagi hidup sehat dan modern menjadi semakin menarik untuk diperbincangkan dan direkomendasikan kepada orang lain. Promo yang diberikan setiap bulannya pun semakin menambah keseruan transaksi jual beli produk Tupperware pada dosen Fakultas Ekonomi Untad.

Atribut produk dan loyalitas pelanggan seperti yang sudah dijelaskan sebelumnya dengan melihat fenomena yang terjadi di ruang lingkup Fakultas Ekonomi Untad menjadikan penulis tertarik untuk melakukan penelitian mengenai produk Tupperware pada kosumen yang loyal. Melihat data dosen dan tenaga kependidikan Fakultas Ekonomi Untad yang berjumlah 160 orang, terdiri dari 106 pria dan 54 wanita, maka penulis juga akan melakukan penelitian pada dosen pria yang akan diwakili oleh istriistri dosen melalui Darma Wanita Fakultas Ekonomi Untad.

\section{Tujuan Penelitian}

Berdasarkan permasalahan di atas, maka tujuan penelitian ini untuk mengetahui:

1. Pengaruh signifikan Atribut Produk (merek, label, kemasan, pelayanan dan garansi) terhadap loyalitas pelanggan Tupperware Studi pada dosen dan tenaga kependidikan Fekon Untad.

2. Pengaruh signifikan merek terhadap loyalitas pelanggan Tupperware studi pada dosen dan tenaga kependidikan Fekon Untad.

3. Pengaruh signifikan kemasan terhadap loyalitas pelanggan Tupperware studi pada dosen dan tenaga kependidikan Fekon Untad.

4. Pengaruh signifikan label terhadap loyalitas pelanggan Tupperware studi pada dosen dan tenaga kependidikan Fekon Untad.

5. Pengaruh signifikan pelayanan terhadap loyalitas pelanggan Tupperware studi pada dosen dan tenaga kependidikan Fekon Untad.

6. Pengaruh signifikan garansi terhadap loyalitas pelanggan Tupperware studi pada dosen dan tenaga kependidikan Fekon Untad.

\section{KAJIAN LITERATURE}

\section{Pengertian Perilaku Konsumen}

Menurut Winardi dalam Sunyoto (2013:3) perilaku konsumen dapat dirumuskan sebagai perilaku yang ditunjukkan oleh orang-orang dalam hal merencanakan, membeli dan menggunakan barangbarang ekonomi dan jasa-jasa. Menurut Sunyoto (2013:4) perilaku konsumen adalah tindakantindakan yang dilakukan oleh individu, kelompok, atau organisasi yang berhubungan dengan proses pengambilan keputusan dalam mendapatkan, menggunakan barang-barang atau jasa ekonomis yang dapat dipengaruhi lingkungan.

\section{Atribut Produk}

Gitosudarmo (2014:124) mengemukakan bahwa atribut produk adalah sifat-sifat atau aspek-aspek yang dimiliki oleh suatu produk yang mana sifat-sifat tersebut akan menjadi pertimbangan konsumen untuk menyenangi atau sebaliknya membenci produk itu.Menurut Guntur dalam Nugroho dkk (2015:2) Atribut produk merupakan segala hal yang melekat pada produk atau menjadi bagian dari produk itu sendiri. Handayani (2012:2) dalam jurnal penelitiannya menulis bahwa atribut produk dapat diartikan sebagai karakteristik yang melekat pada produk dan sebagai pelengkap dari fungsi dasar produk tersebut.

Menurut Peter dan Olson (2014:189) produk dan atribut produk adalah stimulus utama yang memengaruhi afeksi, kognisi, dan perilaku konsumen. Pemasaran dan informasi lain juga memengaruhi pembelian dan penggunaan produk akan memuaskan atau tidak. Peter dan Olson juga 
mengemukakan atribut produk meliputi harga, desain, warna, kualitas, dan merek. Menurut Tjiptono (2008:103) atribut produk adalah usur-unsur yang dianggap penting oleh konsumen dan dijadikan dasar pengambilan keputusan pembelian. Atribut produk meliputi merek, kemasan, label, pelayanan, jaminan (garansi), dan sebagainya.

\section{Merek}

Menurut Undang-Undang RI Nomor 15 Tahun 2001, merek adalah tanda yang berupa gambar nama, kata, huruf-huruf, angka-angka, susunan warna, atau kombinasi dari unsur-unsur tersebut yang memiliki daya pembeda dan digunakan dalam kegiatan perdagangan barang atau jasa (Sunyoto, 2013:51). Tjiptono (2008:104) merek merupakan nama, istilah, tanda, simbol/lambang, desain, warna, gerak, atau kombinasi atribut-atribut lainnya yang diharapkan dapat memberikan identitas dan diferensiasi terhadap produk pesaing. Menurut Kotler and Amstrong (2008:275) merek adalah sebuah nama, istilah, tanda, lambang, atau desain, atau kombinasi dari semua ini yang memperlihatkan identitas produk atau jasa dari satu penjual atau sekelompok penjual dan membedakan produk itu dari produk pesaing. Manfaat merek bagi penjual menurut Laksana (2008:78) adalah:

1. Nama merek memudahkan penjual untuk mengolah pesanan-pesanan dan menekan permasalahan.

2. Nama merek dan tanda dagang secara hukum akan melindungi penjual dari pemalsuan ciri-ciri produk, karena bila tidak demikian, maka setiap pesaing akan meniru produk yang telah berhasil di pasaran.

3. Merek memberi penjual peluang kesetiaan konsumen pada produk.

4. Merek dapat membentu penjual dalam mengelompokan pasar ke dalam segmen-segmen.

5. Citra perusahaan dapat dibina dengan adanya merek yang baik. Dengan membawa nama perusahaan, merek ini sekaligus mengiklankan kualitas dan besarnya perusahaan.

\section{Kemasan}

Pengemasan (Packaging) merupakan proses yang berkaitan dengan perancangan dan pembuatan wadah (Container) atau pembungkus (Wrapper) untuk suatu produk (Tjiptono, 2008:206).

Syarat-syarat pembungkus/kemasan menurut Alma (2011:162) adalah:

1. Sebagai tempat

2. Menarik

3. Dapat melindungi

4. Praktis

5. Menimbulkan harga diri

6. Ketepatan ukuran

7. Pengangkutan, dalam membuat pembungkus harus pula diperhatikan pengaruhnya terhadap ongkos kirim.

Menurut Laksana (2008:82) kemasan adalah segala kegiatan merancang dan memproduksi wadah atau bungkus suatu produk. Kemasan terdiri dari 3 (tiga) tingkat bahan (Sunyoto, 2013:60), yaitu:

1. Kemasan dasar (primary package) yaitu bungkus langsung dari suatu produk, missal botol obat batuk, merupakan kemasan dasar.

2. Kemasan tambahan (secondary package) yaitu bahan yang melindungi kemasan dasar dan dibuang bila produk itu dipergunakan, missal bungkus obat batuk.

3. Kemasan pengiriman (shipping package) yaitu kemasan yang berfungsi untuk penyimpanan dan pengiriman, misal kotak besar yang menjadi tempat selusin obat batuk.

\section{Label}

Pengertian label adalah bagian dari sebuah barang yang berupa keterangan (kata-kata) tentang barang tersebut atau penjualnya. Pengertian yang lain mengenai label yaitu label is the part of a product that carries information about the product or the seller (label adalah bagian sebuah produk yang memberikan informasi tentang produk atau penjualnya), (Sunyoto, 2013:63).

Label adalah bagian dari sebuah barang yang berupa keterangan-keterangan tentang produk tersebut (Laksana, 2008:83). Menurut Laksana, fungsi label yaitu:

1. Label mengidentifikasikan produk atau merek

2. Label berfungsi menggolongkan produk 
3. Menjelaskan beberapa hal mengenai produk, yaitu siapa yang membuat, di mana dibuat, kapan di buat, apa isinya, bagaimana harus digunakan, bagaimana cara menggunakan dengan aman.

4. Sebagai alat promosi.

Macam-macam label menurut Laksana (2008:83) adalah sebagai berikut:

1. Brand identifidies label, yaitu label yang semata-mata sebagai brand merek.

2. Grade label, yaitu label yang menunjukan tingkat kualitas tertentu suatu barang.

3. Descriptive label, yaitu label yang menggambarkan tentang cara penggunaan, pemeliharaan dan features lainnya daripada produk.

\section{Pelayanan}

Menurut Mahmoedin (2010: 2) pelayanan adalah suatu aktivitas atau serangkaiam aktivitas yang bersifat tidak kasat mata yang terjadi sebagai akibat adanya interaksi antara konsumen dengan karyawan atau hal-hal yang disediakan oleh perusahaan pemberi layanan yang dimaksud untuk memecahkan permasalahan konsumen/pelanggan.

Menurut Tjiptono (2008:107) dewasa ini produk apapun tidak terlepas dari unsur jasa atau layanan, baik itu jasa sebagai produk inti (jasa murni) ataupun jasa sebagai pelengkap. Layanan pelengkap diklasifikasikan menjadi delapan kelompok, yaitu sebagai berikut:

1. Informasi, misalnya jalan/arah menuju tempat produsen, jadwal atau skedul penyampaian produk/jasa, harga, instruksi mengenai cara menggunakan produk inti atau layanan pelengkap, peringatan (warnings), kondisi penjualan/layanan, pemberitahuan adanya perubahan, dokumentasi, konfirmasi reservasi, rekapitulasi rekening, tanda terima dan tiket.

2. Konsultasi, seperti pemberian saran, auditing, konseling pribadi, dan konsultasi manajemen atau teknis.

3. Order taking, meliputi aplikasi (keanggotaan di klub atau program tertentu, jasa langganan, jasa berbasis kualifikasi misalnya perguruan tinggi), order entry, dan reservasi (meja, tempat duduk, ruang, professional appointments), admisi untuk fasilitas yang terbatas (contohnya pameran).

4. Hospitality, diantaranya sambutan, food and beverages, toilet dan kamar kecil, perlengkapan kamar mandi, fasilitas menunggu (majalah, hiburan, koran, ruang tunggu), transportasi, dan sekuriti.

5. Caretaking, terdiri atas perhatian dan perlindungan barang yang dibeli konsumen (pengemasan, pengantaran, transportasi, instalasi, pembersihan, diagnosis, inpeksi, pemeliharaan preventif, inovasi, dan upgrades).

6. Exceptions, mencakup permintaan khusus, penyampaian produk menangani komplain atau saran, pemecahan masalah (jaminan atas kegagalan pemakaian produk, kesulitan yang muncul dari pemakaian produk, termasuk masalah dengan stafate konsumen lainnya), dan restitusi (kompensasi, pengembalian uang, dan sebagainya)

7. Billing, mencakup laporan rekening periodik, laporan verbal mengenai jumlah rekening, faktur untuk transaksi individual, mesin yang memperlihatkan jumlah rekening, dan self-billing.

8. Pembayaran, berupa pelanggan berinteraksi dengan personil perusahaan yang menerima pembayaran, kontrol dan verifikasi, serta pengurangan otomatis atas rekening nasabah.

\section{Garansi}

Tjiptono (2008:108) mendefinisikan bahwa garansi adalah janji yang merupakan kewajiban produsen atas produknya kepada konsumen, dimana para konsumen akan diberi ganti rugi bila produk ternyata tidak bisa berfungsi sebagaimana yang diharapkan atau dijanjikan. Tjiptono juga mengemukakan dalam bukunya pemasaran jasa mendefinisikan garansi adalah jaminan kualitas atau umur pemakaian yang diharapkan atas produk yang dijual dan kerapkali disertai dengan janji pengembalian uang, reparasi, atau pengerjaan ulang.

Menurut Hart dalam Tjiptono (2014:492), garansi yang efektif memiliki empat karakteristik:

1. Unconditional, artinya tidak dibarengi dengan beraneka macam restriksi, pembatasan, kondisi, dan persyaratan birokratis.

2. Bermakna (meaningful), yaitu memberikan jaminan atas elemen jasa yang penting bagi pelanggan dan menawarkan kompensasi yang bisa menutupi ketidakpuasan pelanggan (seperti biaya dan tenaga yang telah dikeluarkan).

3. Mudah dipahami dan dikomunikasikan oleh karyawan dan pelanggan.

4. Mudah diminta dan diterima, dalam artian tidak memakan waktu lama. 
Garansi atau lazim pula disebut warranty adalah surat keterangan dari suatu produk bahwa pihak produsen menjamin produk tersebut bebas dari kesalahan pekerja dan kegagalan bahan dalam jangka waktu tertentu. Biasanya pelanggan sebagai pengguna terakhir dan penjual melengkapi pengisian data pada surat keterangan tersebut untuk kemudian dikirim ke produsen agar didaftarkan tanggal mulai periode garansi (Wikipedia.2017).

\section{Loyalitas Pelanggan}

Lovelock, et al (2011:76) mengemukakan Loyalitas merupakan satu kata lama yang biasa digunakan untuk menggambarkan kesetiaan dan kepatuhan terhadap negara, gerakan, atau individu. Belakangan ini loyalitas digunakan dalam konteks bisnis, untuk menggambarkan kesediaan pelanggan agar senantiasa menggunakan produk perusahaan dalam jangka panjang, apalagi jika menggunakannya secara eksklusif, dan merekomendasikan produk-produk perusahaan kepada teman dan rekannya.

Oliver dalam Dimyati (2013:7) mendefinisikan loyalitas pelanggan sebagai komitmen yang dipegang kuat untuk membeli lagi atau berlangganan lagi bagi produk tertentu di masa depan meskipun ada pengaruh situasi dan usaha pemasaran yang berpotensi menyebabkan peralihan perilaku.

Handayani (2012:2) loyalitas pelanggan dapat diartikan sebagai dorongan perilaku untuk melakukan pembelian secara berulang-ulang untuk membangun kesetiaan pelanggan terhadap suatu produk yang dihasilkan oleh perusahaan dengan waktu yang lama melalui proses pembelian yang berulang-ulang tersebut.

\section{Hubungan antara Atribut Produk dan Loyalitas Pelanggan}

Loyalitas pelanggan termasuk perilaku konsumen pascapembelian. Karena itu, adanya pelanggan yang loyal tentu melalui proses pembelian terlebih dahulu. Sebagaimana yang dikemukakan oleh Setiadi (2013:14) bahwa proses pembelian yang spesifik terdiri dari urutan kejadian berikut: pengenalan masalah, pencarian informasi, evaluasi alternatif, keputusan pembelian, dan perilaku pascapembelian. Seperti tampak pada gambar berikut:

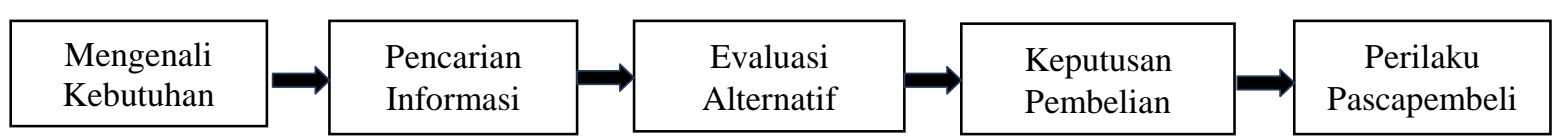

\section{Gambar 1 Proses Pembelian}

Setelah konsumen melakukan keputusan pembelian, konsumen akan membandingkan antara harapannya berdasarkan informasi yang diperoleh dengan kenyataan yang dirasakannya setelah mengonsumsi produk yang dipilih. Hasilnya apakah menimbulkan kepuasan atau ketidakpuasan terhadap produk tersebut. Kotler dan Keller (2009:190) menjelaskan kepuasan merupakan fungsi kedekatan antara harapan dan kinerja anggapan produk. Jika kinerja tidak memenuhi harapan, konsumen kecewa; jika memenuhi harapan, konsumen puas; jika melebihi harapan, konsumen sangat puas. Perasaan ini menentukan apakah pelanggan membeli produk kembali dan membicarakan hal-hal menyenangkan atau tidak menyenangkan tentang produk itu kepada orang lain.

Berikut ini gambaran kerangka pemikiran penelitian: 


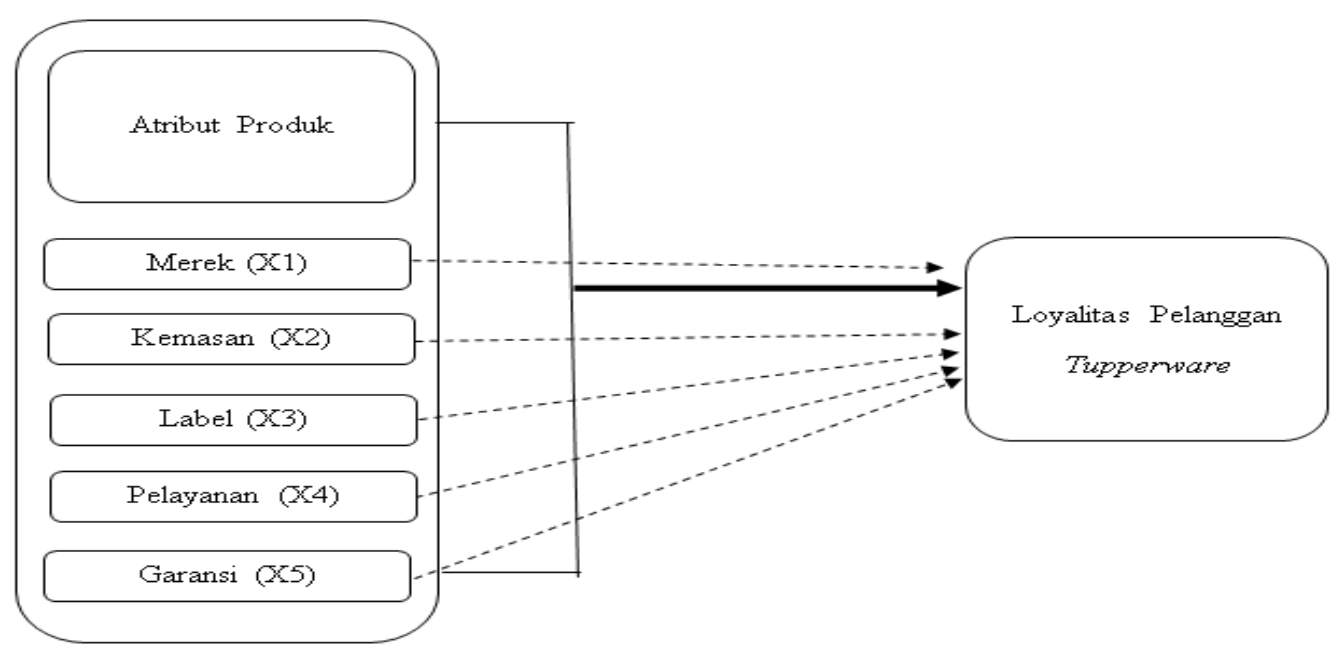

\section{Gambar 2 Kerangka Pemikiran}

\section{Hipotesis}

Berdasarkan judul penelitian, maka penulis dapat merumuskan hipotesis sebagai berikut:

1. Atribut produk [merek (X1), kemasan (X2), label (X3), pelayanan (X4) dan garansi (X5)] secara bersama-sama memiliki pengaruh yang signifikan terhadap loyalitas pelanggan Tupperware studi pada dosen dan tenaga kependidikan Fekon Untad.

2. Merek (X1) memiliki pengaruh yang signifikan terhadap loyalitas pelanggan Tupperware.

3. Kemasan (X2) memiliki pengaruh yang signifikan terhadap loyalitas pelanggan Tupperware.

4. Label (X3) memiliki pengaruh yang signifikan terhadap loyalitas pelanggan Tupperware.

5. Pelayanan (X4) memiliki pengaruh yang signifikan terhadap loyalitas pelanggan Tupperware.

6. Garansi (X5) memiliki pengaruh yang signifikan terhadap loyalitas pelanggan Tupperware.

\section{METODE PENELITIAN}

Penelitian ini merupakan penelitian deskriptif kausal. Penelitian deskriptif kausal bertujuan meneliti kemungkinan adanya sebab-akibat antar variabel. Sehingga penelitian ini akan menguji kemungkinan adanya sebab-akibat antar variabel bebas (X) (atribut produk: merek (X1), kemasan (X2), label (X3), pelayanan (X4), dan garansi (X5)) dengan variabel terikat (Y) loyalitas pelanggan Tupperware. Penelitian ini yang menjadi subyek penelitian adalah dosen dan tenaga kependidikan Fakultas Ekonomi Universitas Tadulako yang loyal menggunakan produk Tupperware dimana dosen pria akan diwakili oleh istrinya melalui Darma Wanita Fakultas Ekonomi Untad. Sedangkan obyek penelitian adalah pengaruh atribut produk yang terdiri dari merek, kemasan, label, pelayanan dan garansi terhadap loyalitas pelanggan Tupperware (studi pada dosen dan tenaga kependidikan Fekon Untad). Adapun teknik-teknik pengumpulan data yang digunakan dalam penelitian ini adalah sebagai berikut:

1. Observasi, adalah cara pengumpulan data melalui proses pencatatan perilaku subjek (orang), objek (benda), atau kejadian yang sistematik tanpa adanya komunikasi dengan sesuatu yang diteliti.

2. Kuesioner merupakan cara pengumpulan data yang menggunakan daftar pertanyaan/pernyataan yang sudah disusun secara cermat oleh peneliti.

3. Studi kepustakaan, yaitu dengan mempelajari berbagai literature, skripsi serta berbagai sumber yang memungkinkan dan berkaitan dengan penelitian ini.

Populasi dalam penelitian ini adalah seluruh dosen dan tenaga kependidikan Fakultas Ekonomi Universitas Tadulako, dimana dosen pria akan diwakili oleh istrinya melalui Darma Wanita Fakultas Ekonomi Universitas Tadulako yang loyal menggunakan produk Tupperware.

Berdasarkan data dosen dan tenaga kependidikan yang penulis peroleh, terdapat jumlah dosen sebanyak 135 orang dan tenaga kependidikan berjumlah 25 orang sehingga total dosen dan tenaga kependidikan Fakultas Ekonomi Universitas Tadulako berjumlah 160 orang. Namun, data tersebut tidak dapat dijadikan sebagai populasi penelitian karena yang menjadi populasi dalam penelitian ini adalah dosen dan tenaga kependidikan Fakultas Ekonomi Universitas Tadulako yang loyal 
menggunakan produk Tupperware. Maka, pengambilan sampel dari penelitian ini penulis menggunakan Nonprobability Sampling dengan teknik pengambilan sampel Purposive Sampling.

Penentuan ukuran sampel yang digunakan pada penelitian ini, penulis merujuk pada saran-saran dari Roscoe tentang ukuran sampel (dalam Sugiyono, 2014 :165) yang mengemukakan bila dalam penelitian akan melakukan analisis dengan multivariate (korelasi atau regresi ganda misalnya), maka jumlah anggota sampel minimal 10 kali dari jumlah variabel yang diteliti. Jumlah variabel dalam penelitian ini adalah 5 yang terdiri dari variabel independen (merek, kemasan, label, pelayanan, dan garansi) dan variabel dependen (loyalitas pelanggan). Berdasarkan hal tersebut maka penulis menetapkan jumlah sampel sebesar $10 \times 6$ variabel yaitu 60 responden, dengan demikian sampel dari penelitian ini adalah sebanyak 60 responden.

Penelitian ini menggunakan aplikasi software SPSS (Statistical Program for Social Scane) versi 22.0 yang dipakai untuk menganalisis pengaruh secara simultan dan pengaruh secara parsial variabel Independen terhadap dependen. Adapun teknik analisis data yang dipergunakan dalam penelitian ini, sebagai berikut:

Model umum bentuk persamaan alat analisis statistik parametrik Regresi Linear Berganda dapat digambarkan sebagai (Sugiyono, 2014:298)

$$
\mathbf{Y}=\mathbf{a}+\mathbf{b}_{1} \mathbf{X}_{1}+\mathbf{b}_{2} \mathbf{X}_{2}+\ldots \ldots+\mathbf{b}_{\mathbf{n}} \mathbf{X}_{\mathbf{n}}
$$

Apabila ditransformasikan ke dalam penelitian ini, maka persamaan regresi linear berganda dapat dirumuskan kembali (Sugiono, 2014:277) seperti berikut:

$$
Y=a+b_{1} X_{1}+b_{2} X_{2}+b_{3} X_{3}+b_{4} X_{4}+b_{5} X_{5}
$$

Keterangan:

Y : Loyalitas Pelanggan

$\alpha \quad$ : Konstanta (Intercept)

$\mathrm{b}_{1}-\mathrm{b}_{5} \quad$ : Koefisien regresi berganda antara variabel bebas $\mathrm{X} 1$ terhadap variabel terikat $\mathrm{Y}$, apabila variabel bebas X2 diangap konstan.

$\mathrm{X}_{1} \quad$ : Merek

$\mathrm{X}_{2}$ : Kemasan

$\mathrm{X}_{3} \quad$ : Label

$\mathrm{X}_{4} \quad$ : Pelayanan

$\mathrm{X}_{5} \quad$ : Garansi

\section{HASIL DAN PEMBAHASAN}

\section{Analisis Regresi Berganda}

\begin{tabular}{|c|c|c|c|c|c|}
\hline \multirow{2}{*}{\multicolumn{2}{|c|}{ Variabel }} & \multicolumn{2}{|c|}{$\begin{array}{c}\text { Unstandardized } \\
\text { Coefficients }\end{array}$} & \multirow{2}{*}{$\begin{array}{c}\begin{array}{l}\text { Standardized } \\
\text { Coefficients }\end{array} \\
\text { Beta }\end{array}$} & \multirow[t]{2}{*}{ Sig. $t$} \\
\hline & & $\mathbf{B}$ & Std. Error & & \\
\hline \multicolumn{2}{|l|}{ (Constant) } & .148 & .529 & & .780 \\
\hline \multicolumn{2}{|l|}{ Merek (X1) } & .259 & .103 & .235 & .015 \\
\hline \multicolumn{2}{|l|}{ Kemasan (X2) } & -.115 & .071 & -.150 & .109 \\
\hline \multicolumn{2}{|l|}{ Label (X3) } & .160 & .077 & .197 & .044 \\
\hline \multicolumn{2}{|l|}{ Pelayanan (X4) } & .241 & .086 & .264 & .007 \\
\hline \multicolumn{2}{|l|}{ Garansi (X5) } & .484 & .074 & .591 & .000 \\
\hline R Square $\left(R^{2}\right)$ & $=0.612$ & & Fhitung & $=17.018$ & \\
\hline Multiple R & $=0.782$ & & Constanta & $=0.148$ & \\
\hline Jumlah data 60 & & & $\mathrm{~F}$ & $=0.000$ & \\
\hline Responden & & & & & \\
\hline
\end{tabular}

Tabel 1. Hasil Perhitungan Regresi Linear Berganda

Sumber: Data diolah kembali 
Berdasarkan Tabel 1 di atas, dapat diperoleh persamaan regresi sebagai berikut:

$$
Y=0,148+0,259 X_{1}-0,115, X_{2}+0,160 X_{3}+0,241 X_{4}+0,484 X_{5}
$$

\section{Pembahasan}

Berdasarkan hasil uji regresi, diperoleh tingkat signifikansi $\mathrm{F}=0,000<\alpha=0,05$ yang berarti bahwa variabel atribut produk yang terdiri dari merek (X1), kemasan (X2), label (X3), pelayanan (X4), dan garansi (X5) secara simultan berpengaruh signifikan terhadap variabel loyalitas pelanggan (Y). Nilai koefisien korelasi sebesar 0,782 atau $78,2 \%$ yang menunjukan besar pengaruh atribut produk terhadap loyalitas pelanggan. Maka berdasarkan pedoman interpretasinya, kedua variabel (bebas dan terikat) memiliki hubungan yang kuat.

\section{Pengaruh Variabel Merek (X1) terhadap Loyalitas Pelanggan Tupperware (Y)}

Berdasarkan uji regresi pada pengujian parsial, diketahui bahwa merek memberi pengaruh yang positif dan signifikan terhadap loyalitas pelanggan Tupperware pada Dosen dan Tenaga Kependidikan Fakultas Ekonomi Universitas Tadulako dengan nilai signifikansi sebesar 0,015. Hal tersebut bermakna bahwa produk Tupperware memiliki merek yang dapat diucapkan, mudah diingat, disenangi pelanggan, dan menggambarkan kualitas produk dapat menjadikan pelanggan loyal terhadap produk plastik Tupperware.

\section{Pengaruh Variabel Kemasan (X2) terhadap Loyalitas Pelanggan Tupperware (Y)}

Variabel kemasan tidak memiliki pengaruh terhadap loyalitas pelanggan Tupperware pada Dosen dan Tenaga Kependidikan Fakultas Ekonomi Universitas Tadulako. Berdasarkan hasil uji regresi pada pengujian parsial, diketahui kemasan memiliki pengaruh yang negatif dan tidak signifikan terhadap loyalitas pelanggan Tupperware dengan nilai signifikansi sebesar 0,109 . Hal tersebut bermakna kemasan yang memberi perlindungan terhadap produk, dengan kemasan, produk Tupperware mudah dibawa, kemasan dapat digunakan kembali, dan kemasan menarik tidak menjadikan pelanggan loyal terhadap produk Tupperware. Ini disebabkan fungsi dari kemasan Tupperware itu sendiri hanya sebagai wadah untuk pengiriman kepada konsumen dimana hanya produk-produk tertentu saja yang memilikinya seperti tempat beras, alat pencetak adonan, alat penggiling yang merupakan wadah peralatan dapur atau paket collection.

\section{Pengaruh Variabel Label (X3) terhadap Loyalitas Pelanggan Tupperware (Y)}

Berdasarkan uji regresi pada pengujian parsial, label memiliki pengaruh yang positif dan signifikan terhadap loyalitas pelanggan Tupperware studi pada Dosen dan Tenaga Kependidikan Fakultas Ekonomi Universitas Tadulako dengan nilai signifikansi 0,044. Ini berarti produk Tupperware yang memiliki katalog, tingkat kejelasan tulisan yang baik, disertai aturan pemakaian dan produk asli mudah dikenali dapat menjadikan pelanggan loyal terhadap produk plastik Tupperware. Dengan kata lain, jika label Tupperware meningkat, loyalitas pelanggan juga meningkat.

\section{Pengaruh Variabel Pelayanan (X4) terhadap Loyalitas Pelanggan Tupperware (Y)}

Berdasarkan hasil uji regresi pada pengujian parsial, ditemukan variabel pelayanan memiliki pengaruh yang positif dan signifikan terhadap loyalitas pelanggan Tupperware studi pada Dosen dan Tenaga Kependidikan Fakultas Ekonomi Universitas Tadulako dengan nilai signifikansi sebesar 0,007. Maka dapat diasumsikan bahwa semakin baik pelayanan yang diberikan, semakin meningkat pula loyalitas pelanggan Tupperware. Hal tersebut juga menunjukan bahwa barang yang diterima sesuai keinginan pelanggan, barang yang dipesan diterima tepat pada waktunya dan informasi mengenai produk mudah diperoleh menjadikan pelanggan loyal terhadap produk Tupperware.

\section{Pengaruh Variabel Garansi (X5) terhadap Loyalitas Pelanggan Tupperware (Y)}

Berdasarkan hasil uji regresi pada pengujian parsial, diketahui variabel garansi memiliki pengaruh yang positif dan signifikan terhadap loyalitas pelanggan Tupperware pada Dosen dan Tenaga Kependidikan Fakultas Ekonomi Universitas Tadulako dengan nilai signifikansi sebesar 0,000 dan memiliki pengaruh yang paling besar dari variabel bebas lainnya dengan besar pengaruh 48,4\% garansi mempengaruhi loyalitas pelanggan. Ini berarti penggantian produk sesuai ketentuan, waktu garansi tak terhingga, tidak dibarengi persyaratan yang rumit, dan prosedur garansi mudah dipahami menjadikan pelanggan loyal terhadap produk Tupperware. 


\section{KESIMPULAN DAN SARAN}

\section{Kesimpulan}

1. Variabel Merek (X1), Kemasan (X2), Label (X3), Pelayanan (X1), dan Garansi (X5) secara simultan berpengaruh signifikan terhadap loyalitas pelanggan Tupperware studi pada Dosen dan Tenaga Kependidikan Fakultas Ekonomi Universitas Tadulako.

2. Variabel Merek (X1) secara parsial berpengaruh signifikan terhadap loyalitas pelanggan Tupperware studi pada Dosen dan Tenaga Kependidikan Fakultas Ekonomi Universitas Tadulako.

3. Variabel Kemasan (X2), secara parsial berpengaruh tidak signifikan terhadap loyalitas pelanggan Tupperware studi pada Dosen dan Tenaga Kependidikan Fakultas Ekonomi Universitas Tadulako.

4. Variabel Label (X3), secara parsial berpengaruh signifikan terhadap loyalitas pelanggan Tupperware studi pada Dosen dan Tenaga Kependidikan Fakultas Ekonomi Universitas Tadulako.

5. Variabel Pelayanan (X4), secara parsial berpengaruh signifikan terhadap loyalitas pelanggan Tupperware studi pada Dosen dan Tenaga Kependidikan Fakultas Ekonomi Universitas Tadulako.

6. Variabel Garansi (X5), secara parsial berpengaruh signifikan terhadap loyalitas pelanggan Tupperware studi pada Dosen dan Tenaga Kependidikan Fakultas Ekonomi Universitas Tadulako.

\section{Saran}

1. Bahwa atribut produk terhadap loyalitas pelanggan Tupperware memiliki nilai koefisien korelasi yang kuat. Peneliti menyarankan agar lebih meningkatkan setiap atribut-atribut produk yang melekat pada Tupperware agar selain terkenal dengan produk plastik berkualitas terbaik, juga semakin disukai karena atribut-atribut lain seperti merek, label, pelayanan, dan garansi.

2. Bahwa walaupun kemasan tidak memiliki pengaruh yang signifikan terhadap loyalitas pelanggan, tetapi penulis menyarankan agar tetap memperhatikan setiap kemasan yang digunakan dalam pengantaran produk kepada pelanggan agar produk tetap terlindungi atau tidak tergores dan lainlain.

3. Kepada perusahaan Tupperware khususnya yang ada di Indonesia haruslah terus mengontrol dan mengevaluasi variabel-variabel yang terbukti memberikan pengaruh yang signifikan terhadap loyalitas pelanggan Tuperware, agar terjadi peningkatan produktifitas dan efektifitas perusahaan yang tentunya akan meningkatkan pula keuntungan bagi perusahaan

4. Diharapkan bagi penelitian sebelumnya yang menjadikan referensi dapat mengombinasikan variabel-variabel yang mempengaruhi loyalitas pelanggan Tupperware agar hasil yang didapatkan lebih maksimal dan memberi kontribusi bagi pihak yang berkepentingan.

\section{REFERENSI}

Alma, Buchari. (2011). Manajemen Pemasaran dan Pemasaran Jasa. Bandung: Alfabeta.

Dimyati, Mohamad. 2013. Model Struktural Pengaruh Atribut Produk Terhadap Kepuasan Dan Loyalitas Pelanggan Produk Pon's. Jurnal Aplikasi Manajemen (JAM) Volume 10 No. 1.

Gitosudarmo, Indriyo. 2014. Manajemen Pemasaran Edisi Kedua. Yogyakarta. BPFE.

Handayani, Novita Tri, 2012. Pengaruh Atribut Produk Terhadap Loyalitas Pelanggan Green Product Sepeda Motor Honda Injection. Management Analisys Journal ISSN 2252-6552.

Kotler, Philip dan Gary Amstrong. 2008. Prinsip-prinsip pemasaran, Edisi keduabelas. Jilid 1. Erlangga, Jakarta

Kotler, Philip dan Kevin Lane Keller (Penyuntingan). 2009. Manajemen Pemasaran, Edisi 13 Jilid 1. Jakarta. Erlangga.

Kotler, Philip dan Kevin Lane Keller (Penyuntingan). 2009. Manajemen Pemasaran, Edisi 13 Jilid 2. Jakarta. Erlangga.

Laksana, Fajar. 2008. Manajemen Pemasaran : Pendekatan Praktis. Yogyakarta. Graha Ilmu.

Lovelock, Wirtz, dan Mussry (Penyuntingan). 2011. Pemasaran Jasa : Manusia, Teknologi, Strategi, jilid 2, Jakarta. Erlangga.

Mahmoedin, As. 2010. Melacak Kredit Bermasalah. Cetakan Pertama. Jakarta. Pustaka Sinar Harapan. 
Nugroho, Nokma Aditya, Suharyono dan Sunarti. 2015. Pengaruh Atribut Produk Terhadap Kepuasan Pelanggan Dan Loyalitas Pelanggan (Survei Pada Counter Perdana Di Gresik). Jurnal Administrasi Bisnis $\quad(J A B) \mid$ Vol. $20 \quad$ No. $1 . \quad$ Retrieved from http://administrasibisnis.studentjournal.ub.ac.id/index.php/jab/article/view/821/1006

Peter, J. Paul dan Jerry C. Olson. 2014. Perilaku Konsumen \& Strategi Pemasaran Edisi 9 Buku 2. Jakarta. Salemba Empat.

Setiadi, Nugroho J. 2013. Perilaku Konsumen. Jakarta: PT. Kharisma Putra Utama.

Sugiyono. 2014. Metode Penelitian Manajemen. Cetakan Ke-3. Jakarta: Alfabeta.

Sugiyono. 2014. Metode Penelitian Bisnis. Cetakan Ke-18. Jakarta: Alfabeta.

Sugiyono. 2014. Metode Penelitian Kuantitatif Kualitatif dan R\&D. Bandung: Alfabeta.

Sunyoto, Danang. 2013. Perilaku Konsumen (Pannduan Riset Sederhana untuk Mengenali Konsumen). Yogyakarta: CAPS.

Tjiptono, Fandy. 2008. Strategi Pemasaran. Yogyakarta: Andi Offset.

Tjiptono, Fandy. 2014. Pemasaran Jasa. Yogyakarta: Andi Offset. 